\title{
Water quality and plankton populations in an earthen polyculture pond
}

\author{
Sipaúba-Tavares, LH. *, Donadon, ARV. and Milan, RN. \\ Centro de Aquicultura, Universidade Estadual Paulista - UNESP, \\ Via de Acesso Prof. Paulo Donato Castellane, s/n, CEP 14884-900, Jaboticabal, SP, Brazil \\ *e-mail: sipauba@caunesp.unesp.br
}

Received July 7, 2010 - Accepted November 8, 2010 - Distributed November 30, 2011

(With 6 figures)

\begin{abstract}
This work was carried out during one year in a fish pond to evaluate the effect of water quality in a plankton community according to the adopted management. High densities of Euglenophyceae, Chlorophyceae and Cyanobacteria were associated with high nitrate levels ( 1 to $\left.210 \mathrm{mg} \cdot \mathrm{L}^{-1}\right)$. Cell densities of Cyanobacteria over 90 ind. $\mathrm{m}^{3} \times 10^{3}(85.5 \%)$ occurred when nitrate concentrations approximated $210 \mathrm{mg} . \mathrm{L}^{-1}$, total phosphorus less than $160 \mathrm{mg} . \mathrm{L}^{-1}$ and temperature above $25{ }^{\circ} \mathrm{C}$. High density of Rotifera was associated with high density of Cyanobacteria (December). Only Trichocerca sp. among the Rotifera species was constant in all sampled sites, whereas Diaphanosoma birgei, ranging between 4 and 342 ind. $\mathrm{L}^{-1}(0.7$ and $2.4 \%)$ during the study period, was the most representative among the Cladocera species. Results show that water quality management in the fish pond had a direct influence on the plankton population due to the shallowness of the environment, large nutrient discharges through feed, fertilizing, fish waste. In fact, they contribute towards the appearance of undesirable plankton organisms.
\end{abstract}

Keywords: fishpond, phytoplankton, zooplankton, limnology, environment management.

\section{Qualidade da água e população planctônica em viveiro de policultivo de peixe}

\section{Resumo}

O presente estudo foi realizado durante um ano em viveiro de produção de peixes, com a finalidade de avaliar o efeito da qualidade da água na comunidade planctônica em função do manejo adotado. Maiores densidades de Euglenophyceae, Chlorophyceae e Cyanobacteria estiveram associadas aos elevados teores de nitrato (1 a $210 \mathrm{mg} . \mathrm{L}^{-1}$ ). Densidades de Cyanobacteria acima de 90 ind. $\mathrm{m}^{3} \times 10^{3}(85,5 \%)$ ocorreram quando as concentrações de nitrato estiveram ao redor de $210 \mathrm{mg} . \mathrm{L}^{-1}$, fósforo total menor que $106 \mathrm{mg} . \mathrm{L}^{-1}$ e temperatura acima de $25^{\circ} \mathrm{C}$. Elevada densidade de Rotifera também esteve associada às altas densidades de Cyanobacteria (dezembro). Dentre os organismos zooplanctônicos, os Rotifera foram os mais abundantes e somente Trichocerca sp. foi constante em todos os pontos amostrados. Dentre os Cladocera, a espécie mais representativa foi Diaphanosoma birgei, variando de 4 a 342 ind.L - $^{-1}(0,7$ e $2,4 \%)$ durante o período de estudo. Os resultados mostram que qualidade da água e o manejo empregado neste viveiro apresentaram influência direta na população planctônica, em função da baixa profundidade e constante carga de nutrientes que são incorporados no viveiro por meio de alimentos, fertilizantes e fezes de peixes, que contribuem para o aparecimento de organismos planctônicos não desejáveis.

Palavras-chave: viveiros, fitoplâncton, zooplâncton, limnologia, manejo ambiental. 


\section{Introduction}

One of the main causes of water quality deterioration is fish pond management. The daily addition of food and fertilization for plankton growth, with a subsequent increase in nutrient rates in the water column, are always required for fish development.

To fill a fish pond, water may come from several sources such as wells, creaks, rivers, reservoirs or other natural sources. Water may either pass through the pond and be discharged or it may be partially retained. Water also contains nutrients, which can stimulate the growth of plankton population, aquatic plants and may also contain great amounts of organic and inorganic matter, which influence water quality of the pond (Adeoye et al., 2009). Furthermore, the feed given daily to fish may not be directly consumed by fish species but may be leached into the pond, affecting all levels of nutrient availability and plankton growth in such systems (Ferdoushi et al., 2008).

Regular fertilization in fish ponds accumulates nutrients at the bottom of the water body. The most limiting nutrients for the plankton population are nitrogen and phosphorus, and the main source of such substances in fish ponds are fish excretion, the protein level in food and release from the sediment. In fact, decomposition of organic matter produces ammonia, which diffuses from sediment to the water column (Hargreaves and Tucker, 2004). High nutrient load and production accumulate organic matter at the bottom sediment which maintains high internal loading (Pokorný and Hauser, 2002).

There is a direct relationship between nutrients and phytoplankton density and species diversity. Chowdhury et al. (2007) observed low abundance of phytoplankton in low temperature and nitrate concentration, although phosphate exhibited an inverse relationship with the growth rate of planktonic organisms. Recent studies have suggested phosphorus as the most limiting nutrient with regard to phytoplankton. As a rule, affinity constants for orthophosphate by Cyanobacteria occurred (Moutin et al., 2002; Tanaka et al., 2004).

Nutrients increase is readily incorporated into the plankton community and ultimately into the fish biomass. Several studies (Naz and Turkemen, 2005; Arimoro et al., 2008; Shan et al., 2008) have reported higher densities of plankton (mainly phytoplankton) during the rainy season owing to the fact that rains carry allochthonous nutrients from the drainage basin as well as mixing of the autochthonous material. Primary production and consequently phytoplankton production and abundance are accelerated (Basualto et al., 2006; Arimoro et al., 2008).

Plankton biomass and composition in shallow water bodies fluctuate as a reaction to several interacting driving forces which may include polymixis, water-level changes, weather conditions, nutrients loading and feeding management (Borics et al., 2000).

In the case of aquaculture, the maintenance of good water quality is of primary importance so that excellent culture environment, adequate feed for optimal fish yield potential, appraisal of the eutrophic situation and increase in plankton population may be achieved. This is because fish pond systems are affected by temporal changes which may cause fluctuations in planktonic population composition and assemblage. Therefore, the present investigation aims at analysing the occurrence and abundance of phytoplankton and zooplankton in a fish pond and their relationship with limnological variables.

\section{Material and Methods}

\subsection{Study area and sampling sites}

Current research was carried out at the Aquaculture Center (21 ${ }^{\circ} 14^{\prime} 05^{\prime \prime} \mathrm{S}$ and $\left.48^{\circ} 17^{\prime} 09^{\prime \prime} \mathrm{W}\right)$, at the Universidade Estadual Paulista (UNESP), Jaboticabal, SP, Brazil, in a fish pond with continuous water flow which provides a daily exchange of $5 \%$ of volume. According to the Köpen classification, the region's climate is Cwa, subtropical, relatively dry in the winter (June to September) and rainy in the summer (October to March), with mean yearly temperature of $22^{\circ} \mathrm{C}$ and at mean of altitude $605 \mathrm{~m}$. The fish pond surface area is $2,036 \mathrm{~m}^{2}$ and the mean depth is $1.30 \mathrm{~m}$. The fish pond was populated with the fish species Piaractus mesopotamicus ("pacu"), Colossoma macropomum ("tambaqui”), Pseudoplatystoma corruscan ("pintado") and Brycon cephalus ("matrinxã") breeders. The total number of fishes was three hundred. Fish were fed with a supplementary diet containing $28 \%$ crude protein. Samples for abiotic and biotic variables determination were undertaken monthly, from December 2007 to November 2008. Water samples were collected at six sampling sites: $\mathrm{P}_{1}=$ back water area; $\mathrm{P}_{2}=$ outlet water; $\mathrm{P}_{3}=$ deep water site; $\mathrm{P}_{4}=$ inlet water from 6 fish ponds of $80 \mathrm{~m}^{2} ; \mathrm{P}_{5}=$ inlet water from 11 fish ponds of $50 \mathrm{~m}^{2}$, and $\mathrm{P}_{6}=$ inlet water from of water supply fish pond, ornamental fish lab and four fish ponds of $200 \mathrm{~m}^{2}$, where the macrophyte stand lies (Figure 1).

\subsection{Plankton}

Sampling for plankton was done using a Van Dorn bottle filtering a volume of $5 \mathrm{~L}$ for phytoplankton and $10 \mathrm{~L}$ to zooplankton. The plankton samples were filtered with 25 and $58 \mathrm{~mm}$ mesh nets, and preserved in Lugol iodine solution and formalin (4\%), respectively, for phytoplankton and zooplankton. Numerical densities data were expressed as ind. $\mathrm{m}^{3} \times 10^{3}$, ind. $\mathrm{L}^{-1}$, and percentage abundance (\%). The concentrated preserved plankton samples were analysed using a Sedgewick-Rafter counting cell and examined under $100 \times$ magnification. Cladocera and Copepoda, were counted in a reticulated chamber. Approximately four hundred individuals of the most abundant species were registered, with an approximate $10 \%$ precision, and a 95\% confidence interval (Bicudo and Bicudo, 2004). Frequency of occurrence was estimated for total phytoplankton and zooplankton organisms were divided into three categories: constant (50\% or above); common (between $10 \%$ and 50\%) and rare (between 1 and 10\%) (Sampaio et al., 2002). 


\subsection{Limnological variables}

Water samples were collected at $0.10 \mathrm{~m}$ depth. Transparency was measured using a Secchi disk, temperature dissolved oxygen and $\mathrm{pH}$ were taken with a multiparametric probe (Horiba U-10), chlorophyll- $a$ was evaluated according to Nusch (1980), nutrients according to Koroleff (1976) and Golterman et al. (1978). All samples were transported to the laboratory in cold boxes.

\subsection{Statistical analysis}

Two-way ANOVA was used for physical and chemical parameters in order to compare sites and months, and their interactions, with significance level of $\mathrm{p}<0.05$ (Fowler et al., 1998). Pearson's correlation $(\mathrm{p}<0.05)$ was used to find out the levels of significance of relationship between groups of phytoplankton and zooplankton and environmental variables, by using the Statistic 6.0 program.

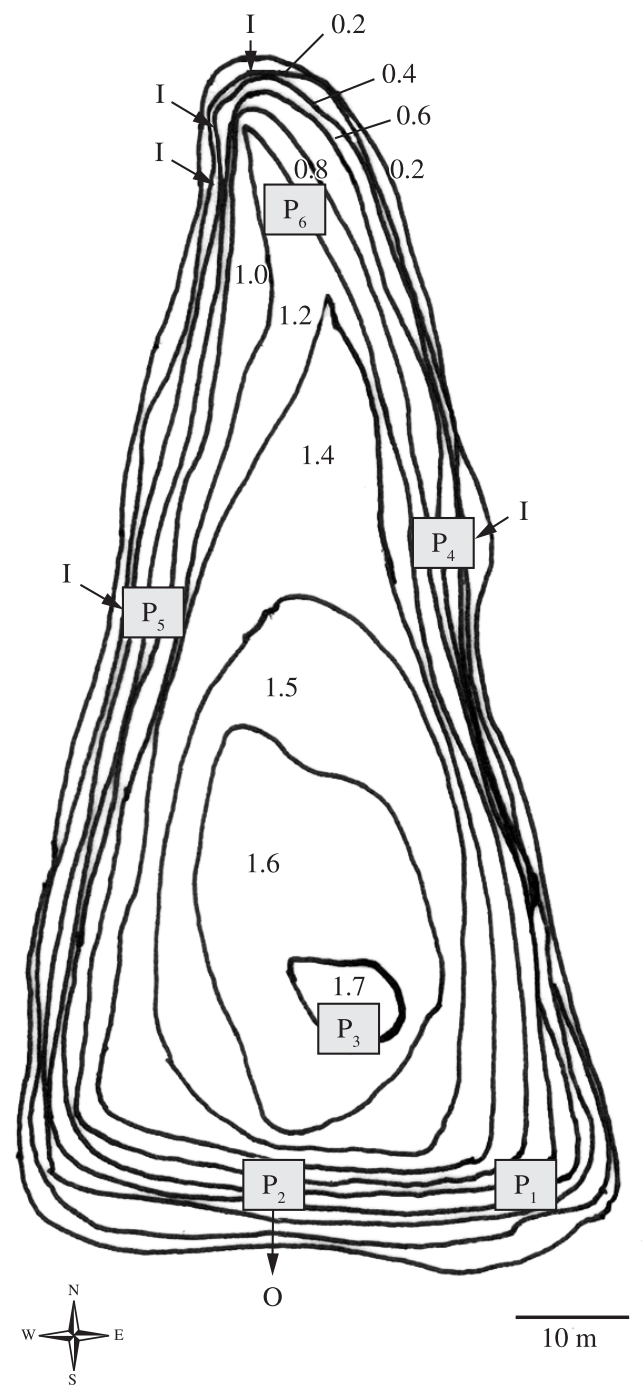

Figure 1. Cross-section of fish pond studied, where: $\mathrm{P}_{1}$ $\mathrm{P}_{6}=$ Ssamples sites; $\mathrm{I}=$ inlet water; $\mathrm{O}=$ outlet water.
Sites were grouped by cluster analysis (unweighted pair group average linkage, UPGMA) based on the Bray Curtis index, using abundance $\log _{10}(\mathrm{x}+1)$ transformed data of all plankton (Magurran, 1989).

\section{Results}

Although a significant difference $(\mathrm{p}<0.05)$ was observed between months, no significant difference ( $p>0.05$ ) was reported between sites when comparing orthophosphate, nitrate and total phosphorus (TP). By contrast, ammonia levels showed significant difference $(p<0.05)$ between sites, but no difference $(p>0.05)$ between months. Dissolved oxygen values varied from 3.0 to $7.3 \mathrm{mg} . \mathrm{L}^{-1}$ with differences $(\mathrm{p}<0.05)$ between sites and months. Although TP in the water column was not high; the highest values were reported in October at $\mathrm{P}_{2}\left(159 \mathrm{mg} \cdot \mathrm{L}^{-1}\right)$. TP and orthophosphate fluctuation rates were similar to those of the highest concentrations reported between June through October. Since during the same period the lowest values were registered with the highest phytoplankton cell densities in the water, there was an inverse relationship between orthophosphate and the different phytoplanktonic groups (Figures 2 and 3).

The Bacillariophyceae group, abundant throughout the study period, was the only exception (Figures 3 ). High nitrate rates, ranging between 1 and 210 mg. $\mathrm{L}^{-1}$, were reported between December and March when the highest cell densities for Euglenophyceae, Chlorophyceae and Cyanobacteria occurred. The Zygnematophyceae group had the highest cell densities in June with 288 ind. $\mathrm{m}^{3} \times 10^{3}$ (76\%) when TP and orthophosphate concentrations in the water column were high. Nitrate concentration was highest at $\mathrm{P}_{1}\left(210 \mathrm{mg} . \mathrm{L}^{-1}\right)$ and TP was lower than $106 \mathrm{mg} . \mathrm{L}^{-1}$, with Cyanobacteria cell densities above 90 ind. $\mathrm{m}^{3} \times 10^{3}$, associated with high temperatures $\left(>25^{\circ} \mathrm{C}\right)$ (Figures 2 and 3 ; Table 1).

Furthermore, $\mathrm{pH}$ was alkaline throughout the research varying between 7.2 and 8.7, except in October at $\mathrm{P}_{3}$, when those values reached 9.9. This fact coincided with high ammonia concentration (175 mg. $\left.\mathrm{L}^{-1}\right)$ during the whole study period, which were more associated with fish feeding management (diet addition). There were no significant differences in $\mathrm{pH}$ values $(\mathrm{p}>0.05)$ between sites and months. Chlorophyll- $a$ values varied from 3 to $56 \mathrm{mg} . \mathrm{L}^{-1}$ and were not significantly different $(p>0.05)$ between sites and months (Figures 2 and 4). A sudden fall in temperature in July directly affected some phytoplanktonic populations with Chlorophyceae, Zygnematophyceae, and Euglenophyceae. Copepoda and Bacillariophyceae were also affected (Figures 3 and 5; Table 1). Transparency was directly related to the fall in temperature values and to the phytoplankton community higher density in July, ranging between 0.7 and $0.9 \mathrm{~m}$ among the sampled sites. Transparency and temperature values were significantly different $(\mathrm{p}<0.05)$ between sites during the year. As a rule dissolved oxygen was above $4 \mathrm{mg} . \mathrm{L}^{-1}$, with significant differences between sites and months $(\mathrm{p}<0.01)$, and inverse relation with temperature (Figure 4). 

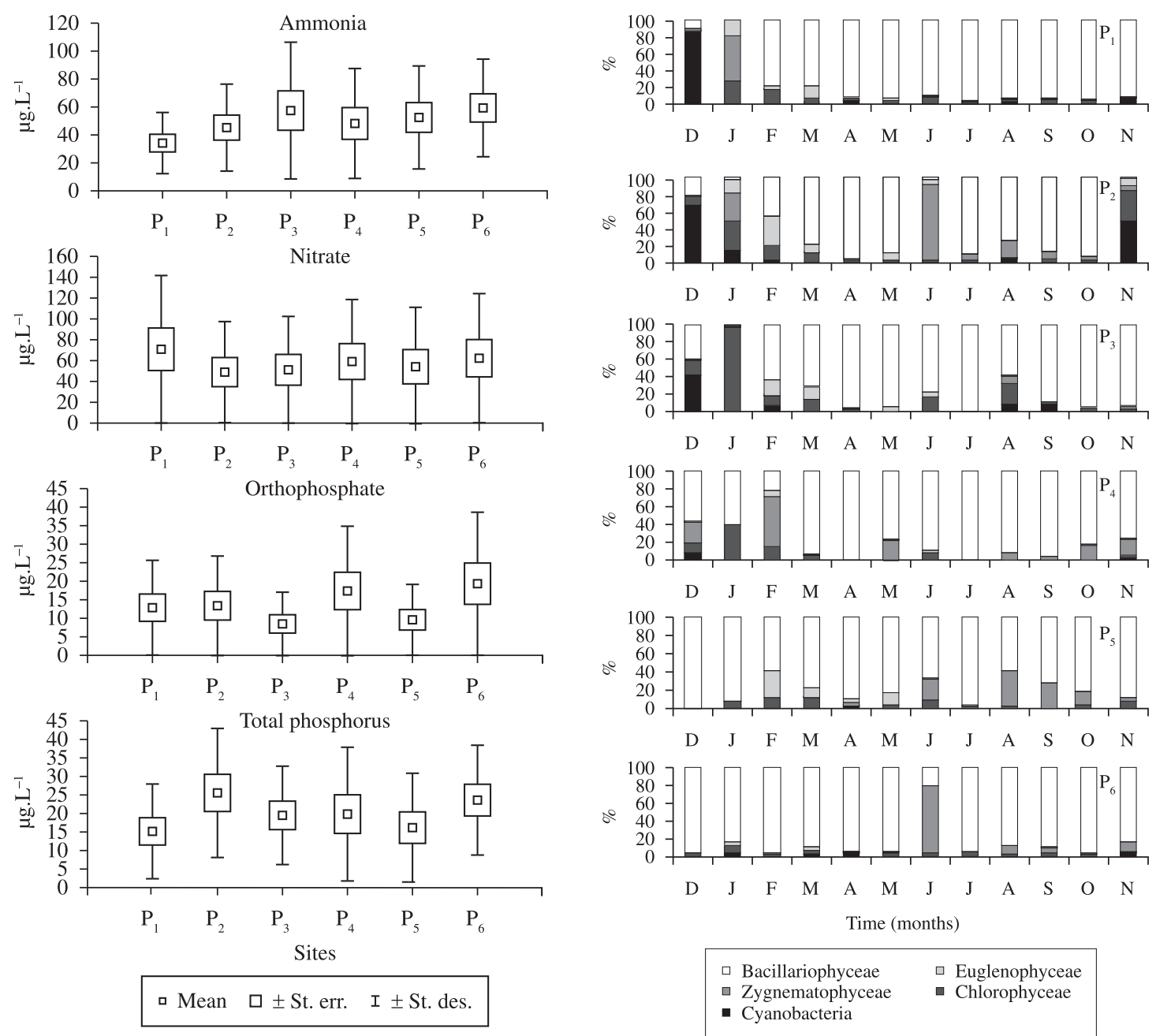

Figure 2. Monthly variation of nutrients at water column of the different samples sites $\left(\mathrm{P}_{1}-\mathrm{P}_{6}\right)$ during the studied period.

The phytoplankton community consisted of 35 taxa during the period under analysis. The Bacillariophyceae group was the most representative, followed by Chlorophyceae, Zygnematophyceae, Euglenophyceae, Cyanobacteria and Oedogonophyceae. The species Oedogonium sp., reported at $\mathrm{P}_{5}$ with a density of 20 ind. $\mathrm{m}^{3} \times 10^{3}$ during December 2007, represented the latter (Table 2). Few phytoplanktonics species were constant (13 species), with occurrence reported at $\mathrm{P}_{1}, \mathrm{P}_{2}$ and $\mathrm{P}_{4}$. The first site had the largest number of constant species (Table 2).

The zooplankton community consisted of 24 taxa, or rather, 4 Cladocera, 2 Copepoda and 18 Rotifera. Copepoda species were constant or common at the sampled sites throughout the period, excepting $\mathrm{P}_{3}$. Only Trichocerca sp. among Rotifera species were constant in all sampled sites, whereas Diaphanosoma birgei, ranging between 4 and 342 ind. $\mathrm{L}^{-1}$ (0.7 and $2.4 \%$ ) during the study period, was the most representative among the Cladocera species

Figure 3. Relative abundance (\%) of phytoplankton groups in the fish pond at the different samples sites $\left(\mathrm{P}_{1}-\mathrm{P}_{6}\right)$ during the studied period.

(Table 3). Zooplankton species were more abundant during the rainy period (December through March) when the high fish diet increase rate and nutrient availability (mainly nitrates) occurred. In fact, high phytoplankton density as food for zooplankton was available. High rates of Cyanobacteria in December at $\mathrm{P}_{1}$ did not influence Rotifera and Copepoda density at this site (Figures 3 and 5; Table 1).

Similarity analyses for plankton densities showed the formation of three groups, $\mathrm{P}_{3}$ and $\mathrm{P}_{2}$ sites were markedly different from the rest with regard to phytoplankton and zooplankton, respectively (Figure 6).

\section{Discussion}

Fish pond morphometry and management mainly enhanced fast nutrient increase during the fish growing period which occurred during the rainy period in the southeastern region of Brazil. The amount of organic and inorganic load, introduced in the fish pond and originating 
Table 1. Pearson's correlation between environmental variables and phytoplankton and zooplankton groups.

\begin{tabular}{|c|c|c|c|c|c|c|}
\hline Variables & $\mathbf{P}_{1}$ & $\mathbf{P}_{2}$ & $\mathbf{P}_{3}$ & $\mathbf{P}_{4}$ & $\mathbf{P}_{5}$ & $\mathbf{P}_{6}$ \\
\hline \multicolumn{7}{|l|}{ Phytoplankton } \\
\hline Bacillariophyceae and Nitrate & 0.43 & - & - & -0.50 & - & - \\
\hline Bacillariophyceae and Orthophosphate & 0.30 & - & - & 0.47 & - & -0.30 \\
\hline Bacillariophyceae and Total Phosphorus & - & - & - & 0.51 & -0.36 & - \\
\hline Bacillariophyceae and Temperature & -0.36 & -0.22 & 0.35 & -0.50 & 0.20 & 0.38 \\
\hline Bacillariophyceae and Dissolved Oxygen & - & - & -0.51 & 0.25 & -0.40 & - \\
\hline Chlorophyceae and Nitrate & - & 0.74 & 0.73 & 0.50 & - & 0.54 \\
\hline Chlorophyceae and Temperature & - & 0.43 & 0.50 & 0.56 & 0.33 & 0.45 \\
\hline Chlorophyceae and Transparency & - & - & 0.36 & - & 0.53 & -0.32 \\
\hline Chlorophyceae and Dissolved Oxygen & -0.41 & -0.33 & -0.28 & -0.26 & -0.33 & - \\
\hline Cyanobacteria and Nitrate & 0.57 & - & 0.58 & - & - & -0.12 \\
\hline Cyanobacteria and Temperature & 0.34 & 0.50 & 0.32 & 0.38 & 0.28 & 0.44 \\
\hline Cyanobacteria and Transparency & -0.18 & -0.09 & -0.20 & -0.07 & -0.09 & -0.03 \\
\hline Cyanobacteria and Dissolved Oxygen & - & -0.38 & - & -0.24 & - & -0.43 \\
\hline Euglenophyceae and Nitrate & - & 0.69 & 0.73 & 0.50 & 0.37 & - \\
\hline Euglenophyceae and Orthophosphate & -0.38 & -0.44 & -0.35 & - & - & -0.41 \\
\hline Euglenophyceae and Transparency & 0.60 & - & 0.14 & -0.39 & - & - \\
\hline Euglenophyceae and Total Phosphorus & - & -0.40 & - & - & -0.31 & -0.69 \\
\hline Euglenophyceae and Temperature & 0.21 & 0.29 & 0.30 & - & 0.28 & 0.28 \\
\hline Euglenophyceae and Dissolved Oxygen & -0.43 & - & -0.23 & - & - & -0.35 \\
\hline Zygnematophyceae and Nitrate & -0.31 & - & - & 0.64 & -0.31 & - \\
\hline Zygnematophyceae and Total Phosphorus & - & - & - & - & 0.56 & 0.57 \\
\hline Zygnematophyceae and Transparency & 0.15 & - & -0.36 & - & 0.53 & - \\
\hline Zygnematophyceae and Temperature & - & -0.46 & 0.31 & 0.37 & -0.30 & -0.39 \\
\hline Zygnematophyceae and Dissolved Oxygen & - & 0.56 & -0.21 & -0.38 & 0.33 & 0.37 \\
\hline \multicolumn{7}{|l|}{ Zooplankton } \\
\hline Cladocera and Nitrate & - & 0.48 & 0.77 & 0.40 & 0.84 & 0.41 \\
\hline Cladocera and Temperature & 0.48 & - & 0.57 & 0.30 & 0.43 & 0.31 \\
\hline Cladocera and Orthophosphate & - & -0.30 & - & -0.31 & 0.53 & -0.34 \\
\hline Cladocera and Transparency & - & 0.59 & -0.30 & - & -0.58 & -0.35 \\
\hline Cladocera and Dissolved Oxygen & -0.34 & -0.21 & -0.27 & - & -0.35 & - \\
\hline Copepoda and Nitrate & 0.66 & -0.53 & - & 0.35 & 0.41 & 0.47 \\
\hline Copepoda and Orthophosphate & 0.32 & - & 0.38 & - & - & 0.46 \\
\hline Copepoda and Temperature & - & 0.49 & -0.45 & - & - & -0.40 \\
\hline Copepoda and Transparency & - & - & - & - & - & -0.37 \\
\hline Copepoda and Dissolved Oxygen & - & - & -0.27 & - & -0.23 & -0.21 \\
\hline Rotifera and Nitrate & 0.66 & -0.53 & - & 0.35 & 0.41 & 0.47 \\
\hline Rotifera and Temperature & 0.32 & - & 0.38 & - & - & 0.46 \\
\hline Rotifera and Orthophosphate & - & 0.49 & -0.45 & - & - & -0.40 \\
\hline Rotifera and Transparency & - & - & - & - & - & -0.37 \\
\hline Rotifera and Dissolved Oxygen & -0.38 & -0.45 & -0.30 & - & -0.22 & -0.24 \\
\hline
\end{tabular}



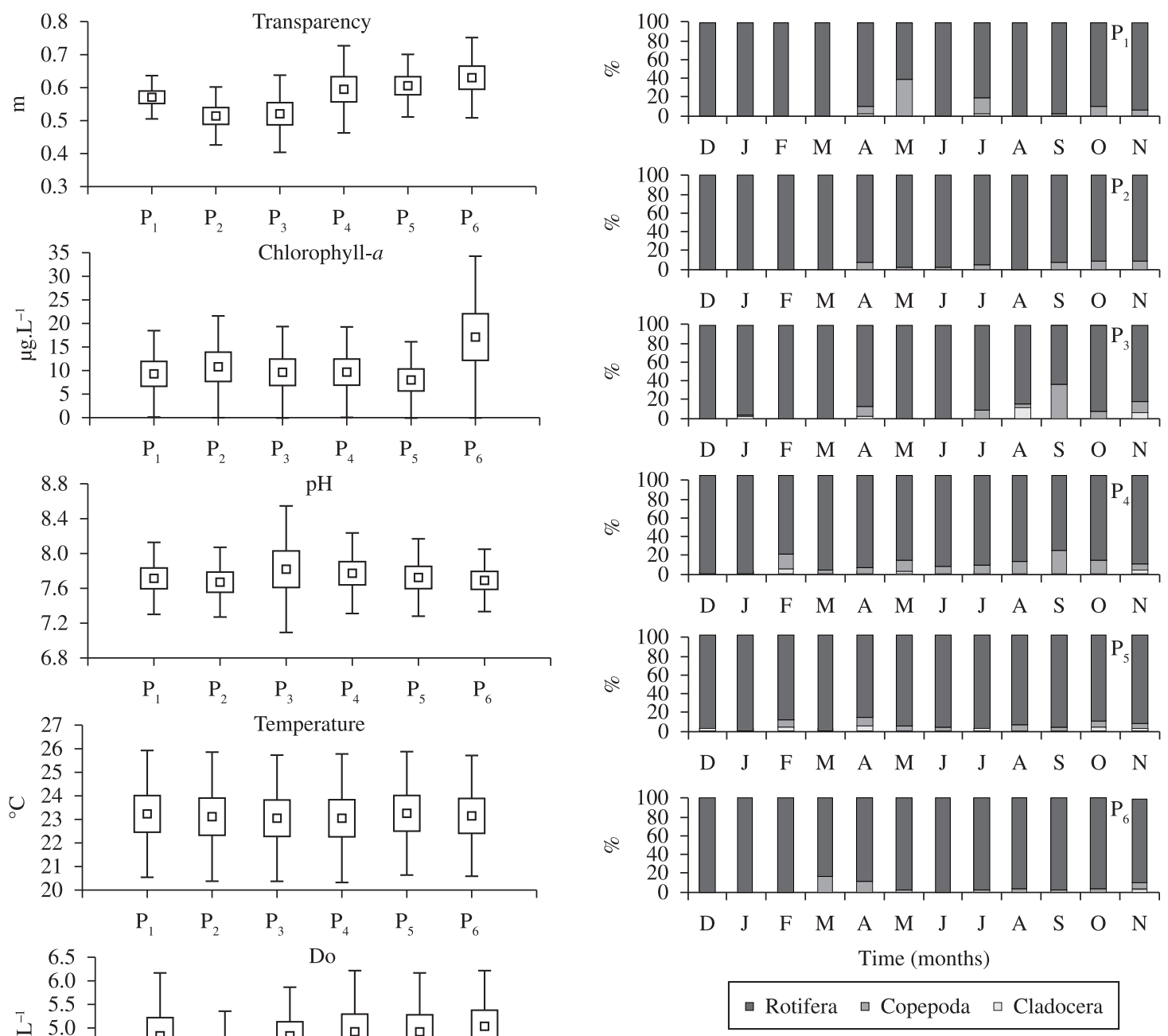

Figure 5. Relative abundance (\%) of zooplankton groups in the fish pond at the different samples sites $\left(\mathrm{P}_{1}-\mathrm{P}_{6}\right)$ during the studied period.

Klaoudatos, 2008). The above was confirmed in current research since high nitrate concentrations, when compared with other nutrients (TP, orthophosphate and ammonia), may be associated with dissolved oxygen above $4 \mathrm{mg} . \mathrm{L}^{-1}$ and the continuous water flow which is heightened during the summer when heavy rains occur.

Ammonia nitrogen is the most important and readily available nitrogen source for phytoplankton. In the current study, ammonia concentrations were lower than $135 \mathrm{mg} . \mathrm{L}^{-1}$ (except in $\mathrm{P}_{3}$ in October), probably due to the fast ammonia uptake by phytoplankton, mainly by Bacillariophyceae species, with high cell densities at most sampled sites throughout the whole studied period. The relatively low ammonia concentrations between November and December (summer) may be attributed the competitive advantage for Cyanobacteria due to high affinity ammonium uptake. Low ammonia concentration between May and July (winter) is associated with the cyclic feeding regimes (periods of feed deprivation followed by re-feeding) in fish production and its variability is due to biological activity (Neofitou and 
Table 2. Specific composition (SC), and frequency occurrence (F) of phytoplankton taxa in the fish pond at the sites $\left(\mathrm{P}_{1}-\mathrm{P}_{6}\right)$.

Taxa

\begin{tabular}{|c|c|c|c|c|c|}
\hline$P_{1}$ & $\mathbf{P}_{2}$ & $\mathbf{P}_{3}$ & $\mathbf{P}_{4}$ & $\mathbf{P}_{5}$ & $P_{6}$ \\
\hline SC F & SC & SC & SC F & SC F & SC F \\
\hline
\end{tabular}

\section{Bacillariophyceae}

Asterionella formosa (Hassall)

Cymatopleura sp.

Melosira sp.

Navicula sp.

Nitzschia amphibia (Grunow)

Pinnularia sp.

Surirella sp.

Tabellaria fenestrata (Lyngb.) Kütz

\section{Chlorophyceae}

Ankistrodesmus falcatus (Corda) Ralfs

Chlorella vulgaris (Kesser \& Huss)

Coelastrum sp.

Coelastrum microporum (Nägeli) Kützing

Coelastrum reticulatum (Dangeard) Senn

Dictyosphaerium pulchellum (Wood)

Gloeocystis sp.

Gloeocytis vesiculosa (Nägeli)

Kirchneriella lunaris (Kirchner) Möbius

Pediastrum duplex (Meyen)

Pediastrum tetras (Ehrenberg) Ralfs

Scenedesmus acuminatus (Largerheim) Chodat

Scenedesmus curvatus (Bohlin)

Scenedesmus ecornis (Ehrenberg) Chodat

Scenedesmus quadricauda (Turpin) Brébison

Tetraedron trigonum (Nägeli) Hansgirg

\section{Cyanobacteria}

Anabaena sp.

Microcystis sp.

Nodularia sp.

\section{Euglenophyceae}

Euglena sp.

Phacus sp.

\section{Oedogoniophyceae}

Oedogonium sp.

\section{Zygnematophyceae}

Pleurotaenium coronatum (Brébison) Rabenhorst

Spirogyra majuscula (Kützing)

Spondylosium rectangulare (Wolle)

Staurastrum leptacanthum (Först)

Staurastrum sp.

$$
\begin{array}{llllllllllll}
+ & \phi & + & \phi & + & \phi & - & - & - & - & - & - \\
- & - & + & \phi & - & - & - & - & + & \phi & + & \phi \\
+ & \bullet & + & 0 & + & 0 & + & 0 & + & 0 & + & 0 \\
+ & \phi & + & \phi & + & \phi & + & \phi & + & \phi & - & - \\
+ & \bullet & + & 0 & + & \phi & + & \phi & + & \phi & + & \phi \\
+ & 0 & + & \bullet & + & \phi & + & \phi & + & \phi & + & \phi \\
+ & 0 & + & \bullet & + & \phi & + & \phi & + & \phi & + & \phi \\
+ & \phi & + & \phi & + & \phi & + & \phi & + & \phi & - & -
\end{array}
$$$$
+\phi+\phi+\phi+\phi+\phi+\phi
$$$$
+\mathrm{o}+\phi+\phi
$$$$
+\mathrm{O}+\mathrm{O}+\phi
$$$$
+\quad+\mathrm{O}+\mathrm{O}+\mathrm{O}+\mathrm{O}+\mathrm{O}
$$$$
+\mathrm{O}+\mathrm{O}+\mathrm{O}+\mathrm{O}+\mathrm{O}+\mathrm{O}
$$$$
+\quad+\mathrm{O}+\mathrm{O}+\mathrm{O}+\mathrm{O}+\mathrm{O}
$$

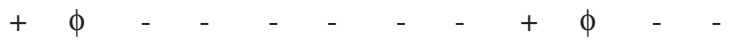$$
+\quad+\mathrm{O}+\mathrm{O}+\mathrm{O}+\mathrm{O}+\mathrm{O}
$$$$
+0+\phi+\phi+\phi+\phi+\phi
$$$$
+\quad+\mathrm{O}+\mathrm{O}+\mathrm{O}+\mathrm{O}+\mathrm{o}
$$$$
+\mathrm{O}+\phi+\phi+\mathrm{O}+\mathrm{O}+\mathrm{O}
$$$$
+\mathrm{o}+\phi+\phi+\phi+\phi+\phi
$$$$
+\phi+\phi
$$$$
+\phi+\phi+\phi-\quad+\quad+\phi-
$$$$
+\quad+\mathrm{O}+\mathrm{O}+\mathrm{O}+\mathrm{O}+\mathrm{O}
$$$$
+\mathrm{O}+\bullet+\mathrm{O}+\mathrm{O}+\phi
$$

$$
\begin{array}{llllllllllll}
+ & \mathrm{o} & + & \mathrm{o} & + & \mathrm{o} & + & \mathrm{o} & + & \mathrm{o} & + & \phi \\
+ & \mathrm{o} & + & \bullet & + & \mathrm{o} & + & \phi & + & \mathrm{o} & + & 0 \\
+ & \phi & + & \phi & - & - & - & - & - & - & - & -
\end{array}
$$

$$
\begin{array}{lllllllllll}
+ & \phi & + & 0 & + & 0 & + & 0 & + & \phi & +
\end{array}
$$

where: $+=$ presence; $-=$ absence; $\bullet=$ constant; $\mathrm{o}=$ common and $\phi=$ rare. 
Table 3. Specific composition (SC), and frequency occurrence (F) of zooplankton taxa in the fish pond at the sites $\left(\mathrm{P}_{1}-\mathrm{P}_{6}\right)$.

\section{Taxa}

$\frac{P_{1}}{S C F} \frac{P_{2}}{S C F} \frac{P_{3}}{S C F} \frac{P_{4}}{S C F} \frac{P_{5}}{S C F} \frac{P_{6}}{S C F}$

\section{Cladocera}

Alona monachanta Sars, 1901

Bosmina hagmani Stingelin, 1904

Bosmina longirostris Muller, 1785

Diaphanosoma birgei Korinek, 1981

\section{Copepoda}

Argyrodiaptomus furcatus Sars, 1901

nauplii

Termocyclops minutus Lowndes, 1934

nauplii

\section{Rotifera}

Ascomorpha saltans Kolisko, 1938

Asplanchna sp.

Asplanchnopus girodi Guerne, 1988

Brachionus caudatus Barrois \& Daday, 1894

Brachionus falcatus Zacharias, 1898

Colurella obtusa (Gosse, 1886) Hauer, 1936

Epiphanes sp.

Hexarthra intermedia Haver, 1953

Keratella cochlearis Gosse, 1851

Lecane sp.

Lecane elsa Hauer, 1931

Lecane lunaris Ehrenberg, 1832

Lecane scutata Harring \& Myers, 1926

Polyarthra dolichoptera Idelson, 1925

Proales sp.

Proales doliaris Rousselet, 1895

Proales globulifera Hauer, 1921

Trichocerca sp.

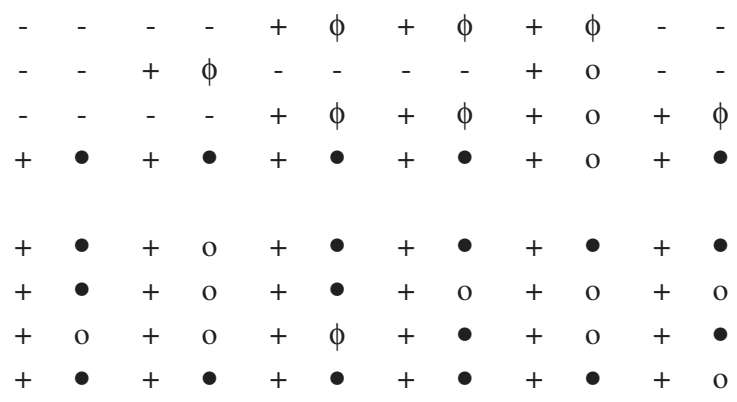

$+\phi-1+\phi+0+0$

$+\mathrm{O}+\phi-\mathrm{O}_{-}+\phi+\phi$

$+\mathrm{O}-\mathrm{O}+\mathrm{O}+\mathrm{O}+\mathrm{O}-\mathrm{O}_{-}$

$+\bullet+\mathrm{O}+\bullet+\bullet+\bullet$

$+\mathrm{O}+\mathrm{O}+\mathrm{O}-\mathrm{O}_{-}+\mathrm{O}-$

$+\quad+\mathrm{O}+\mathrm{O}+\phi+\bullet+\bullet$

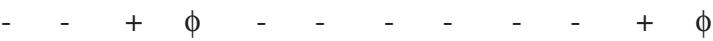

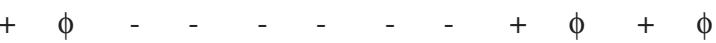

+0 - $-\quad+\phi-D_{-}+\bullet+\phi$

$+\mathrm{O}+\bullet+\bullet+\mathrm{O}+\mathrm{O}+\bullet$

$+\mathrm{O}+\mathrm{O}+\mathrm{O}+\mathrm{O}-\mathrm{O}^{-} \phi$

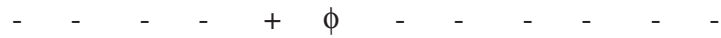

$\begin{array}{llllllllllllll}- & - & + & - & - & - & - & - & - & - & - & - & - & -\end{array}$

$+\quad+\mathrm{O}-\mathrm{O}^{-} \mathrm{O}+\mathrm{O}+\mathrm{O}$

$+\phi+\phi-{ }_{0}+\phi-{ }_{0}+\phi$

$+\mathrm{O}+\mathrm{O}+\mathrm{O}-\mathrm{O}+\mathrm{O}$

+0 - 0 - $-40+\phi-$

$+\bullet+\bullet+\bullet+$

where: $+=$ presence; $-=$ absence; $\bullet=$ constant; $o=$ common and $\phi=$ rare

attempt to mimic the natural fluctuation in prey availability and trigger compensatory growth (Turano et al., 2008).

Euglenophyceae and Cyanobacteria are common groups in small eutrophic water bodies such as fish ponds, oxbow, slow flowing canals (Borics et al., 2000). The cyanobacteria group has a better development in warm temperatures, high light intensity and high levels of phosphorus and nitrogen. Since phosphorus and nitrogen are commonly found in fertilizers used in fish ponds and relatively high temperatures are favourable conditions for the growth of Cyanobacteria (Rahman and Jewel, 2008), the taxon was dominant at temperatures above $20{ }^{\circ} \mathrm{C}$, alkaline $\mathrm{pH}$ and high nutrient concentration (Wilson et al., 2006). These data confirm findings in the present study. Alkaline natural water with hypolimnion oxygen deficit and an occurrence of Cyanobacteria phytoplankton, especially Microcystis sp. are indicative of the eutrophic nature of the water body (Rahman and Jewel, 2008). Results showed that when the density of Cyanobacteria was higher, 90 ind. $\mathrm{m}^{3} \times 10^{3}$ (85.5\%), the most representative group was Microcystis sp., with $65 \%$ of total cells in $\mathrm{P}_{1}$ during December. Jewel et al. (2006) reported that Cyanobacteria cell density increased as a function of mean nitrogen. Management practices of fish ponds, such as high allochthonous nutrients loading, results in massive development of phytoplankton and Cyanobacteria water blooms and high fluctuations of physical-chemical parameters (Pokorný and Hauser, 2002).

Cyanobacteria are also known to deeply affect zooplankton community structure and secondary production (Tillmans et al., 2008). Generally, Cyanobacteria are a poor food source for freshwater grazers, when compared to small Chlorophyceae and/or flagellates. Besides, Cladocera and Rotifera populations are affected differently by distinct Cyanobacteria morphologies (Wilson et al., 2006). In this study, Cladocera density was affected by high densities of Cyanobacteria ( $\mathrm{P}_{1}$ in December), which has not been 


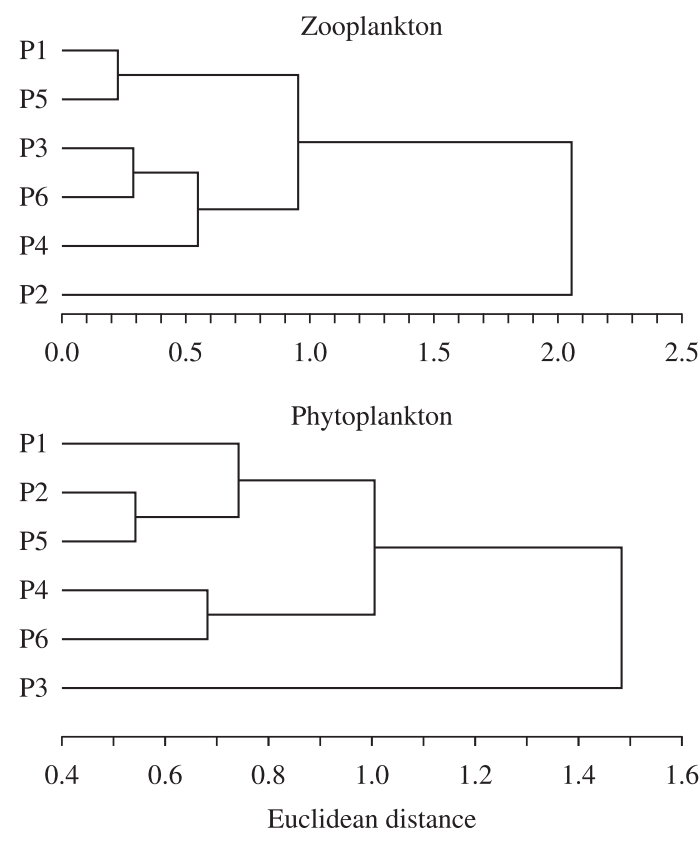

Figure 6. Cluster analysis considering the average total densities of phytoplankton (ind. $\mathrm{m}^{3} \times 10^{3}$ ) and zooplankton (ind. $\mathrm{L}^{-1}$ ) at the samples sites in the fish pond. Abundance data were transformed to $\log _{10}(\mathrm{x}+1)$.

reported for Rotifera species. This may be due to the fact that density of Rotifera at $\mathrm{P}_{1}$, was mainly represented by carnivorous species, such as Polyarthra dolichoptera, Asplanchna sp. and Thrichocerca sp., during the period.

The high density of Rotifera in the fish pond studied has been associated with high density of Cyanobacteria (December). According to Gilbert (1990), Cyanobacteria prevent the suppression of Rotifera by large Cladocera and lead towards the dominance of Rotifera. Several studies have demonstrated the effects of Cyanobacteria on Copepoda filtration rate, egg, production and survival (Ruokolainen et al., 2006; Wilson et al., 2006; Rahman and Jewel, 2008). Copepoda density decreased when high cell density of Cyanobacteria in $\mathrm{P}_{1}$ occurred in December and less representative in $\mathrm{P}_{3}$ in February and September; and in $\mathrm{P}_{1}$ and $\mathrm{P}_{2}$ in November. An increasing trend in Copepoda species occurred between May to July when Cyanobacteria density decreases. Evidence suggests that Cyanobacteria are low quality food for Copepoda owing to their protease inhibitors (Ruokolainen et al., 2006). The greatest abundances of Cyanobacteria were observed in the site $\mathrm{P}_{1}$ where orthophosphate concentration was at its lowest Cyanobacteria abundance might have been influenced by a favourable N:P ratio. Further shallow systems are characterised by phosphate limitation because the biologically available phosphorus amount is small when the quantity required for algal growth is take into consideration (Neofitou and Klaoudatos, 2008). Orthophosphate concentrations in the current study were lower than $50 \mathrm{mg} . \mathrm{L}^{-1}$, except at the $\mathrm{P}_{6}$ (September) site. This is probably due to high macrophytes density at the site $\left(\mathrm{P}_{6}\right)$ which leads to high organic content. The $\mathrm{P}_{6}$ site exhibited great amounts of allochthonous materials coming from other fish ponds that directly discharge their load into the water body under analysis. This fact is supported by low orthophosphate concentrations corresponding to high plankton abundance from December to March.

In this study, phosphorus and nitrogen concentrations were below characteristic eutrophication conditions, which are $0.3 \mathrm{mg} . \mathrm{L}^{-1}$ for nitrogen and $0.001 \mathrm{mg} . \mathrm{L}^{-1}$ for phosphorus in fish ponds, considering the maximum value recommended as an environmental quality standard to avoid eutrophication (Neofitou and Klaoudatos, 2008). The opposite behaviour was observed with chlorophyll- $a$, which has shown concentrations of over $10 \mathrm{mg} . \mathrm{L}^{-1}$.

High rates of nutrients supply often constitute a large fraction of the photosynthetic biomass. Predominance of Bacillariophyceae species throughout the period under analysis has been associated with alkaline water, because acidic waters do not support an abundance of species and show high activity at relatively low temperature (Allen et al., 2005). Kumar and Oommen (2009) reported that acidic waters do not support an abundance of Bacillariophyceae, whereas their density is higher in alkaline waters, with $\mathrm{pH}$ above 8.0, and diatom growth is stimulated by nitrate. In this investigation alkaline $\mathrm{pH}$ (between 7.2 and 8.8) except at $\mathrm{P}_{3}$ in October, and high nitrate concentrations, supported a high population of diatoms.

A high load of organic matter (dead algal cell, fish feed solids, uneaten feed) in bottom sediments is related to the fish pond's fertilization management featuring plankton densities, high quantities of non-consumed remains and consequently large metabolites produced by fish, mainly in the growing fish period during the rainy and hot season. In fact, the fish pond under analysis, receives effluents from other ponds which contribute with large organic and inorganic loads into the system. The above mentioned are also responsible for high nitrate concentrations and organic matter associated with the large amounts of organic input originating from effluent discharge.

Transparency indicates the presence and absence of food particles and productivity of a water body, which is influenced by suspended materials, silt and microorganisms (Ferdoushi et al., 2008). The above pattern was highly evident in the current analysis. When high transparency occurred in July, the Chlorophyceae, Zygnematophyceae and Euglenophyceae cell densities were below 17 ind. $\mathrm{m}^{3} \times 10^{3}(6.7 \%)$ and Cyanobacteria were practically absent. The quantitative and qualitative abundance of plankton and its relationship to environmental conditions are a prerequisite for fish production. In fact, plankton productivity depends on the ecological balance between the various physical-chemical factors (Chowdhury et al., 2007). In general, the highest transparency values were observed at $\mathrm{P}_{6}$ close to the macrophyte stand. Water bodies with medium and dense macrophytes cover are characterised by low concentration of suspended sediments; hence, their 
high water transparency. Water transparency is reduced when opposite occurred (Ferdoushi et al., 2008).

Moreover, dissolved oxygen has been found to be considerably high in colder months (June to August). The plankton community, on which the whole aquatic population depends, is largely affected by an interaction of a number of limiting factors such as low dissolved oxygen, moderate sulphate, nitrate, phosphate and other factors (Kumar and Oommen, 2009).

According to cluster analysis for plankton, the sites influenced by allochthonous materials (organic and inorganic) of other fish ponds were very similar. $\mathrm{P}_{3}$ and $\mathrm{P}_{2}$ sites exhibited the highest differences when compared to other sites. Such differences may be associated with depth $\left(\mathrm{P}_{3}\right)$ and strong water flow $\left(\mathrm{P}_{2}\right)$, especially at this particular water outlet which directly discharges into the subsequent pond.

Management procedures (stocking densities, feeding, sediment removal, fertilizing) of fish ponds are the key to sustainable fish production and directly affect the ecological processes developing in the water column. Variations of the physical and chemical parameters in a fish pond reveal that the limnological conditions in the fish pond are not spatially homogenous, since differences have been observed not only between the different sampling months, but also between the different sites analysed. Based on the results of the current analysis, water quality management in the fish pond shows a direct influence on planktonic population, since fish ponds are shallow and constantly receive large nutrient loads (feed, fertilizing, fish waste) which contribute towards algal growth, Cyanobacteria and undesired zooplanktonic organisms. Excessive phytoplankton growth could be avoided by limiting nutrients to plankton growth through fish feed deprivation periods. The length of the latter may be sufficient so that phosphorus and nitrogen may be depleted and phytoplankton abundance decreased (Turano et al., 2008).

In summary, the fish pond studied was dominated by diatoms and green algae, while Cyanobacteria were more frequent during the summer. In general, whereas reported high phytoplankton density was registered in February and March (summer), zooplankton density occurred between December and March (summer). The maintenance of macrophytes at one of the fish pond's water inlet sites $\left(\mathrm{P}_{6}\right)$ was an asset for the retention of great organic and inorganic load from other ponds beyond that studied. Limnological conditions in the fish pond in fact affected the development of the different components of the plankton population during the period analysed. Future studies aiming at evaluating the effect of adequate management of water quality on planktonic population are thus encouraged.

Acknowledgements - The authors would like to thank the "Fundação de Amparo a Pesquisa do Estado de São Paulo" (FAPESP) for a scholarship (07/59214-9) and financial support (08/53159-9).

\section{References}

ADEOYE, PA., MUSA, JJ. and AKINYEMI, BA., 2009. Design of aerated lagoon for fish pond wastewater treatment. Journal of Turkish, vol. 13, no. 3, p. 188-192.

ALLEN, AE., WARD, BB. and SONG, B., 2005. Characterization of diatom (Bacillariophyceae) nitrate reductase genes and their detection in marine phytoplankton communities. Journal of Phycology, vol. 41, no. 1, p. 95-104. http://dx.doi.org/10.1111/ j.1529-8817.2005.04090.x

ARIMORO, FO., EDEMA, NE. and AMAKA, RO., 2008. Phytoplankton community responses in a perturbed tropical stream in the Niger Delta, Nigeria. Tropical Freshwater Biology, vol. 17 , no. 1 , p. $37-52$.

BASUALTO, S., TAPIA, J., CRUCES, F., BERTRAN, C., SCHLATTER, R., PEÑA-CORTÉS, F. and HAUENSTEIN, E., 2006. The effect of physical and chemical parameters on the structure and composition of the phytoplankton community of lake Budi (IX Region, Chile). Journal of the Chilean Chemical Society, vol. 51, no. 3, p. 993-999. http://dx.doi.org/10.4067/ S0717.970.7200600.030.0015

BICUDO, CEM. and BICUDO, DC., 2004. Amostragem em Limnologia. São Carlos: Rima. 351 p.

BORICS, G., GRIGORZKY, I., SZABÓ, S. and PADISÁK, J., 2000. Phytoplankton associations in a small hypertrophic fish pond in east Hungrary during a change from bottom-up to topdown control. Hydrobiologia, vol. 424, no. 1-3, p. 79-90. http:// dx.doi.org/10.1023/A:100.394.8827254

CHOWDHURY, MMR., MONDOL, MRK. and SARKER, C., 2007. Seasonal variation of plankton population of Borobila beel in Rangpur district. University Journal of Zoology, Rajshahi University, vol. 26, no. 5, p. 49-54.

FERDOUSHI, Z., HAQUE, F., KHAN, S. and HAQUE, M., 2008. The effects of two aquatic floating macrophytes (Lemna and Azolla) as biofilters of nitrogen and phosphate in fish ponds. Turkish Journal of Fisheries and Aquatic Sciences, vol. 8, p. 253-258.

FOWLER, J., COHEN, L. and JARVIS, P., 1998. Practical statistics for field biology. 2nd ed. New York: John Wiley and Sons. $259 \mathrm{p}$

GILBERT, JJ., 1990. Differential effect of Anabaena affins on cladocerans and rotifers: Mechanisms and implications. Ecology, vol. 71, no. 5 , p. 1727-1740. http://dx.doi.org/10.2307/1937581

GOLTERMAN, HL., CLYMO, RS. and OHNSTAD, MAM., 1978. Methods for physical and chemical analysis of fresh water. $2 \mathrm{ed}$. Oxford: Blackwell Scientific Publication, 213 p.

HARGREAVES, JA. and TUCKER, CS., 2004. Managing ammonia in fish ponds. Southern Regional Aquaculture Center, no. 4603 , p. $1-7$

JEWEL, MAS., RAHMAN, MM. and SARKER, MA., 2006. Effects of environmental parameters on the cyanobacterial bloom in a lake of Bangladesh. Bangladesh Journal of Progressive Science and Technology, vol. 4, no. 2, p. 159-164.

KOROLEFF, F., 1976. Determination of nutrients. In GRASHOF, E. and KREMLING, E. (Eds.). Methods of seawater analysis. German: Verlag Chemie Wenhein. p. 117-181.

KUMAR, NJI. and OOMMEN, C., 2009. Influence of limiting factors on phytoplankton and coliform population in an inundated, isolated wetland. Journal of Wetlands Ecology, vol. 3, p. 43-55. 
MAGURRAN, AE., 1989. Diversidad ecológica y su medición. Barcelona: Ediciones Vedrá. 200 p.

MISCHKE, CC. and ZIMBA, P., 2009. Initial influence of fertilizer nitrogen types on water quality. Aquaculture Research, vol. 40 , no. 7, p. 1-5.

MOUTIN, T., THINGSTAD, TT., WAMBEKE, FV., MARIE, D., SLAWYK, G., RAIMBAULT, P. and CLAUSTRE, H., 2002. Does competition for nanomolecular phosphate supply explain the predominance of the cyanobacterium Synechococcus. Limnology and Oceanography, vol. 47, no. 5, p. 1562-1567. http://dx.doi. org/10.4319/lo.2002.47.5.1562

NAZ, M. and TURKEMEN, M., 2005. Phytoplankton biomass and species composition of Lake Golbasi (Hatay - Turkey). Turkish Journal of Biology, vol. 29, p. 49-56.

NEOFITOU, N. and KLAOUDATOS, S., 2008. Effect of fish farming on the water column nutrient concentration in a semi-enclosed gulf of the eastern Mediterranean. Aquaculture Research, 2008, vol. 39, no. 5, p. 482-490. http://dx.doi.org/10.1111/j.13652109.2008.01900.x

NUSCH, EA., 1980. Comparison of different methods for chlorophyll and phaeopigments determination. Archive für Hydrobiolgie, vol. 14, p. 4-36.

POKORNÝ, J. and HAUSER, V., 2002. The restoration of fish ponds in agricultural landscapes. Ecological Engineering, vol. 18, no. 5, p. 555-574. http://dx.doi.org/10.1016/S0925-8574(02)00020-4

RAHMAN, MM. and JEWEL, MAS., 2008. Cyanobacterial blooms and water quality in two urban fish ponds. University Journal of Zoology, Rajshahi University, vol. 27, p. 79-84.

RUOKOLAINEN, L., LILLEY, TM., TAMMI, M. and VUORINEN, I., 2006. Zooplankton in relation to cyanobacteria across a geographic gradient in Archipelago Sea, northern Baltic. Boreal Environmental Research, vol. 11, no. 20, p. 1-11.
SAMPAIO, EV., ROCHA, O., MATSUMURA-TUNDISI, T. and TUNDISI, JG., 2002. Composition and abundance of zooplankton in the limnetic zone of seven reservoirs of the Paranapanema River, Brazil. Brazilian Journal of Biology, vol. 6, no. 3, p. 525-545.

SHAN, MR., HOSSAIN, Y. BEGUM, M., AHMED, ZF., OHTOMI, J., RAHMAN, MM., ALAM, J., ISLAM, A. and FULANDA, B., 2008. Seasonal variations of phytoplankton community structure and production in relation environmental factors of the south west coast waters of Bangladesh. Journal of Fisheries and Aquatic Sciences, vol. 3, no. 2, p. 102-103. http:// dx.doi.org/10.3923/jfas.2008.102.113

TANAKA, T., RASSOULZADEGAN, F. and THINGSTAD, TF., 2004. Orthophosphate uptake by heterotrophic bacteria, cyanobacteria, and autotrophic nanoflagellates in Villefranche Bay, northwestern Mediterranean: Vertical, seasonal, and shortterm variations of the competitive relationship for phosphorus. Limnology and Oceanography, vol. 49, no. 4, p. 1063-1072. http://dx.doi.org/10.4319/1o.2004.49.4.1063

TILLMANS, AR., WILSON, AE., PICK, FR. and SARNELLE, O., 2008. Meta-analysis of cyanobacterial effect on zooplankton population growth rate: species-specific responses. Fundamental and Applied Limnology Archiv für Hydrobiologie, vol. 171, no. 4, p. 285-295.

TURANO, MJ., BORSKI, RJ. and DANIELS, HV., 2008. Effects of cyclic feeding on compensatory growth of hybrid striped bass (Morone chrysops $\mathrm{x}$ M. saxtilis) food fish and water quality in production ponds. Aquaculture Research, vol. 39, no. 14, p. 15141523. http://dx.doi.org/10.1111/j.1365-2109.2008.02023.x

WILSON, AE., SARNELLE, O. and TILLMANNS, AR., 2006. Effects of cyanobacterial toxicity and morphology on the population growth of freshwater zooplankton: Meta-analyses of laboratory experiments. Limnology and Oceanography, vol. 51, no. 4, p. 19151924. http://dx.doi.org/10.4319/lo.2006.51.4.1915 
